\title{
Alternatives of Control of Dawn Crop and Crop Mole in Pre-Harvest in Peasant Fruit
}

\author{
Vicente Luíz de Carvalho, Rodrigo Luz da Cunha, Ângelo Albérico Alvarenga, \\ Pedro Henrique Abreu Moura, José Clélio de Andrade, Paulo Márcio Norberto \\ Agricultural Research Company of Minas Gerais, EPAMIG, Campus UFLA, Lavra, Brazil \\ Email:vicentelc@epamig.ufla.br
}

How to cite this paper: de Carvalho, V.L. da Cunha, R.L. Alvarenga, Â.A., Moura, P.H.A., de Andrade, J.C. and Norberto, P.M. (2019) Alternatives of Control of Dawn Crop and Crop Mole in Pre-Harvest in Peasant Fruit. Agricultural Sciences, 10, 17-24.

https://doi.org/10.4236/as.2019.101002

Received: December 6, 2018

Accepted: January 5, 2019

Published: January 8, 2019

Copyright $\odot 2019$ by author(s) and Scientific Research Publishing Inc. This work is licensed under the Creative Commons Attribution International License (CC BY 4.0).

http://creativecommons.org/licenses/by/4.0/

\begin{abstract}
Fruit rot, besides causing losses in production, reduces the final quality of the product interfering in the commercialization. The objective of this work was to evaluate the efficiency of alternative products applied to pre-harvest for control of brown rot (Monilinia fructicola) and soft rot (Rhizopus spp.) In peaches. The experiment was conducted in the municipality of Nepomuceno-MG, in a peach orchard of the cultivar Diamante. The experimental design was a randomized block design with 7 treatments and 3 replicates, with field plots formed by 12 plants (arranged in 3 rows), being considered for the evaluations only the two central plants. Three applications were made at flowering and at 21; 7 and 3 days before harvest, with solutions containing the following treatments: 1 -Clove oil $0.1 \%$; 2 -silicate clay $1.5 \%$; 3 -Phosphite $\mathrm{K}$ $0.20 \%$; 4-Benzalkonium chloride $0.25 \%$; 5-Azoxystrobin $0.02 \%$; 6-Iprodione $0.15 \%$; 7 -Witness (water only). Treatments 4 and 5 were applied only at 21 and 7 days before harvest. Ten fruits were selected and placed in sterile trays under uncontrolled conditions, with disease evaluations at 3 and 6 days after the beginning of storage in 2005 and at 3; 6 and 9 days in 2006. The iprodione controlled the incidence of $M$. fructicola and had no effect on Rhizopus spp. Clove oil controlled the incidence and severity of $M$. fructicola by the fifth day and Rhizopus spp. by the sixth day. The phosphites of $\mathrm{k}$, benzalkonium chloride and azoxystrobin were efficient in controlling the incidence and severity of Rhizopus spp. and had no effect on $M$. fructicola.
\end{abstract}

\section{Keywords}

Peach, Fruit Rot, Pre-Harvest Control

\section{Introduction}

The production of peach in Brazil in the last four decades has achieved a re- 
markable expansion, reducing drastically the import of this fruit. This was possible thanks to the work developed by the research, such as genetic improvement and adaptation by means of evaluation of cultivars and cultural treatments, such as grafting seedlings, pruning systems, breaking of dormancy through chemical spraying, irrigation use, thinning and protection of fruits through bagging and spraying [1]. In 2015, Brazil produced around 216 thousand tons, in an area of 17.436 hectares and an average productivity of $12.4 \mathrm{t} / \mathrm{ha}$ [2].

Despite the promising future for peach production in Brazil, some post-harvest diseases may compromise activity. Among them, brown rot (Monilinia fructicola) and soft rot (Rhizopus spp.), which are the most important and responsible for damages in the quantity and quality of peach fruits [3] [4] [5].

The control of these diseases is based on a series of preventive measures, beginning in the phases of flowering and pre-harvest with the sanitization of the orchard and continues in the post-harvest including the chemical treatment of the fruits [3] [6] [7] [8] [9].

Replacing the use of agrochemicals with alternative methods or less toxic products is a major challenge for the fruit production chain. The production of quality fruits, guaranteeing the minimum use of agrochemicals and the smallest impact on man and the environment is an objective of Integrated Production and a fundamental factor in marketing strategy in marketing [10].

In this sense, new formulations aiming at the induction or increase of resistance by physical barriers, chemical composition, phytoalexin production, sanitizers and others have been tested.

The use of natural substances makes the products more attractive to the consumer because they do not present toxic effect, even when used in relatively high concentrations. In addition to the benefits provided to health, several studies have demonstrated the inhibitory effect of natural products on the development of pathogenic microorganisms.

In this context, several studies have involved the inhibitory activity of essential oils and clove extract on fungi [11] [12] [13]. Caryophyllus aromaticus L., known as clove because of its origin, contains from $14 \%$ to $20 \%$ volatile oil in dry floral buds, consisting of eugenol (70\% to 95\%), eugenol acetate and a-caryophyllene (5\% to $8 \%$ ). It has germicidal, antiseptic, disinfectant and local anesthetic action [14]. The clove powder showed 100\% inhibition of the mycelial development of fungi Aspergillus niger, Rhizopus spp., Eurotriun repus, Penicillium spp. [15].

Products such as phosphites are emerging in the market as an alternative to disease management. The phosphites can act directly inhibiting the development of fungi and also indirectly stimulating the plant defense system through induction to phytoalexin production [16] [17].

The phosphites used in the post-harvest treatments of fruits have shown a good efficiency in the control of rot. [18], working with potassium phosphite in post-harvest applications managed to control more than $85 \%$ of the latent lesions of M. fructicola. [19] concluded that post-harvest phosphite-K (0.75 to 
$\left.1.5 \mathrm{~mL} \cdot \mathrm{L}^{-1}\right)$ and phosphite- $\mathrm{CaB}\left(1.5\right.$ to $\left.3.0 \mathrm{~mL} \cdot \mathrm{L}^{-1}\right)$ reduced the incidence of mold-blue on apples.

However [8] concluded that the $\mathrm{Ca}$ and B phosphite used in the pre-harvest was not effective in controlling brown rot in peach trees.

Silicon is another element that is being associated with the induction of resistance in plants [20] and that promotes, among other benefits to the plant, greater resistance to the attack of diseases, mainly those caused by fungi [21].

Research from several cultures confirms the potential of silicon in reducing the incidence and severity of disease. Studies have shown that silicate fertilization is effective in reducing the brown spot intensity and bruzone in rice [22].

Foliar application of $1.5 \%$ silicated clay reduced the incidence and especially the severity of papaya smallpox [23].

The application of calcium silicate in coffee plants promoted a reduction of $63.2 \%$ in the number of lesions of C. cofeicola and $43 \%$ of diseased leaves, to a large extent due to a thick cuticle and a more developed wax layer depending on the application of this product [24].

Among the less toxic products that can be used in the fruit sanitization process in the post-harvest phase are chlorinated solutions and benzalkonium chloride. Benzalkonium chloride was not efficient in the post-harvest control of passion fruit rot when kept at $80-90 \%$ Relative Humidity [25].

Benzalkonium chloride at all concentrations used inhibited the growth of Monilinia fructicola in the curative tests and inoculated without injury and was not efficient on Rhizopus spp. [26].

\section{Methodology}

The experiment was carried out in the municipality of Nepomuceno-MG, Brazil, in a peach field of the cultivar Diamante, whose plants were 10 years old, grown in the spacing of $6.0 \mathrm{~m} \times 4.5 \mathrm{~m}$.

The experimental design was in randomized blocks, with plots in the field formed by 12 plants, two useful plants in three replicates. The treatments and concentrations used were: 1 -Clove oil $0.1 \%$; 2 -Silicate clay $1.5 \%$; 3 -Phosphite $\mathrm{K}$ $0.20 \%$; 4-Benzalkonium chloride $0.25 \%$; 5-Azoxystrobin $0.02 \%$; 6-Iprodione $0.15 \%$; 7 -Witness without chemical treatment.

The treatments started in the flowering phase, when the plants received 3 applications: the first in the pink bud stage, the second in full bloom and the third in the fall of the sepals, and followed in the preharvest, at 21, 7 and 3 days before harvest. Azoxystrobin and benzalkonium chloride treatments were applied only at 21 and 7 days before harvest due to the grace period. The applications were performed with motorized costal spray, with the amount of syrup determined after a blank test of around 2 liters per plant.

The evaluations of the diseases were carried out with the fruits at the ideal harvest point, and 30 fruits were collected around each plant, making 60 fruits per plot, of which 15 perfect fruits were selected in the first year (2014) and 8 fruits in the second year (2015), without injury and without disease symptoms. The fruits 
were stored in plastic trays lined with paper towel, left under uncontrolled conditions. Each tray corresponded to an experimental plot in the laboratory.

The incidence and severity of the diseases were evaluated at 3 and 5 days after the beginning of storage in 2014 and at 3; 6 and 9 days in 2015, and recorded the number of fruits with symptoms of the diseases. To assess the severity, the lesions were scored as follows: $1 \%$ to $25 \%$ of the fruit with injury; $2 \%-6 \%$ to $50 \%$; $3 \%-51 \%$ to $75 \%$ and $4 \%>75 \%$. The severity of each fruit was evaluated and the grades obtained per plot were averaged.

The analysis of variance was performed according to the usual model for randomized blocks, in a plot scheme subdivided in time, for the variables studied. The comparison between the measurements of the different treatments was carried out by the Scott-Knott test at the 5\% probability level using the SISVAR software [27].

\section{Results and Discussion}

It should be noted that in the first year of evaluation (2014), brown rot prevailed due to Monilinia fructicola (Table 1), whereas in the second year (2015), the soft rot caused by Rhizopus spp. predominated. This occurrence was natural, probably influenced by the environment.

The results indicate that the treatment with iprodione applied in the flowering stage (pink bud, full bloom and sepals fall) and pre-harvest (21, 7 and 3 days before harvest) significantly reduced the incidence of brown rot up to the fifth day after treatment. This result confirms the efficiency of iprodione, a product commonly used in fruit growing, with good results in the control of brown rot, as verified by [3] [8].

Clove oil at $0.1 \%$ and $0.02 \%$ azoxystrobin applied at the flowering and preharvest stage, and under the conditions under which the experiments were conducted were intermediates in controlling the disease. It stands out mainly the oil of clove for being a product of natural origin. Although it has not found any reference to the effect of clove oil on Monilinia fructicola, several studies have shown the effect of this essential oil on other fungi such as: Aspergillus flavus and A. versicular [11], Aspergillus niger, Rhizopus spp., Eurotriun repus, Penicillium spp. [15].

Regarding the severity (Table 1 ) in the evaluations performed at 3 and 5 days after harvest, clove oil and iprodione, although not statistically different from the other treatments, showed a tendency to reduce the severity of brown rot, confirming the results obtained for incidence.

$\mathrm{K}$ phosphite in the dosage of $0.20 \%, 1.5 \%$ silicated clay and $0.25 \%$ benzalkonium chloride, applied in the flowering and preharvest phases were not efficient in controlling brown rot. As for phosphite of $\mathrm{K}$, the results are comparable to those found by [8]. The silicon contained in the silicate clay, applied in the flowering and pre-harvest phases and in the conditions under which the experiment was conducted, did not induce resistance to the peach tree plant, unlike results found by [22], for brown spot and bruzone in rice, and by [23] for 
Table 1. Incidence and severity of brown rot in peach fruits at 3 and 5 days after different pre-harvest treatments in 2014.

\begin{tabular}{ccccc}
\hline \multirow{2}{*}{ Treatments } & \multicolumn{2}{c}{ Incidence (\%) } & \multicolumn{2}{c}{ Severity (\%) } \\
\cline { 2 - 5 } & 3 days & 5 days & 3 days & 5 days \\
\hline 1-Clove oil & $24.45 \mathrm{~b}$ & $51.11 \mathrm{a}$ & $16.50 \mathrm{a}$ & $35.03 \mathrm{a}$ \\
2-Silicate clay & $48.89 \mathrm{c}$ & $64.45 \mathrm{~b}$ & $26.80 \mathrm{a}$ & $47.30 \mathrm{a}$ \\
3-Phosphite of K & $44.44 \mathrm{c}$ & $68.89 \mathrm{~b}$ & $21.93 \mathrm{a}$ & $45.97 \mathrm{a}$ \\
4-Benzalkonium chloride & $40.00 \mathrm{c}$ & $64.45 \mathrm{~b}$ & $22.80 \mathrm{a}$ & $40.77 \mathrm{a}$ \\
5-Azoxystrobin & $28.89 \mathrm{~b}$ & $57.78 \mathrm{~b}$ & $17.17 \mathrm{a}$ & $38.77 \mathrm{a}$ \\
6-Iprodione & $15.55 \mathrm{a}$ & $42.22 \mathrm{a}$ & $11.50 \mathrm{a}$ & $30.17 \mathrm{a}$ \\
7-Witness & $57.78 \mathrm{~d}$ & $73.34 \mathrm{~b}$ & $27.17 \mathrm{a}$ & $43.60 \mathrm{a}$ \\
CV (\%) & 11.37 & 11.37 & 14.88 & 14.88 \\
\hline
\end{tabular}

Means followed by distinct letters in columns, differ by Scott Knott-5\% test. Data transformed into arc seno $\sqrt{x}$.

incidence and severity of papaya smallpox. In this study, benzalkonium chloride at $0.25 \%$ was not effective in controlling brown rot. However, work of [26], with 1; 2 and $3 \mathrm{ml} / \mathrm{l}$ of benzalkonium chloride showed curative activity, reducing the incidence of $M$. fructicola inoculated in peaches without injuries.

In the second year of the experiment, there was a predominance of soft rot caused by Rhizopus spp.

The results of the evaluation of the incidence of the disease, performed three days after the harvest, showed that there was no significant difference in the incidence of soft rot among the treatments. However at six days, treatments with clove oil, $\mathrm{K}$ phosphite, benzalkonium chloride and azoxystrobin significantly reduced the incidence of brown rot in relation to the other treatments (iprodione and silica clay), although it did not differ statistically from the control (Table 2).

In the last evaluation, at nine days after harvest, the $\mathrm{K}$ phosphite, benzalkonium chloride and azoxystrobin treatments significantly reduced the incidence of soft rot in relation to the other treatments.

Regarding the severity (Table 2) it was verified that there was no significant difference in the evaluation performed three days after the harvest. At six days, treatments with azoxystrobin and clove oil maintained the severity of the disease below the other treatments, although they did not differ statistically from the control. And in the last evaluation, at nine days, in addition to treatment with azoxystrobin, treatments with $\mathrm{K}$ phosphite and benzalkonium chloride were efficient in controlling the severity, confirming the results obtained for incidence.

Azoxystrobin reduced the incidence of soft rot even when only two applications were applied (21 and 7 days before harvest) respecting the grace period.

The product iprodione used as a standard fungicide for the control of brown rot was not efficient in controlling the soft rot caused by Rhizopus spp. 
Table 2. Incidence and severity of soft rot in peach fruits at 3, 6 and 9 days after different pre-harvest treatments in 2015.

\begin{tabular}{ccccccc}
\hline \multirow{2}{*}{ Treatments } & \multicolumn{3}{c}{ Incidence (\%) } & \multicolumn{3}{c}{ Severity (\%) } \\
\cline { 2 - 7 } & 3 days & days & 9 days & 3 days & days & 9 days \\
\hline 1-Clove oil & $4.17 \mathrm{a}$ & $8.33 \mathrm{a}$ & $66.67 \mathrm{~b}$ & $3.33 \mathrm{a}$ & $6.67 \mathrm{a}$ & $32.07 \mathrm{~b}$ \\
2-Silicate clay & $4.17 \mathrm{a}$ & $33.33 \mathrm{~b}$ & $70.83 \mathrm{~b}$ & $9.77 \mathrm{a}$ & $22.23 \mathrm{~b}$ & $48.07 \mathrm{~d}$ \\
3-Phosphite of K & $0.00 \mathrm{a}$ & $8.33 \mathrm{a}$ & $20.83 \mathrm{a}$ & $0.00 \mathrm{a}$ & $14.50 \mathrm{~b}$ & $21.93 \mathrm{a}$ \\
4-Benzalkonium chloride & $4.17 \mathrm{a}$ & $8.33 \mathrm{a}$ & $29.17 \mathrm{a}$ & $4.73 \mathrm{a}$ & $13.53 \mathrm{~b}$ & $23.80 \mathrm{a}$ \\
5-Azoxystrobin & $0.00 \mathrm{a}$ & $0.00 \mathrm{a}$ & $20.83 \mathrm{a}$ & $0.00 \mathrm{a}$ & $0.00 \mathrm{a}$ & $17.73 \mathrm{a}$ \\
6-Iprodione & $4.17 \mathrm{a}$ & $20.83 \mathrm{~b}$ & $54.17 \mathrm{~b}$ & $3.33 \mathrm{a}$ & $17.53 \mathrm{~b}$ & $37.23 \mathrm{c}$ \\
7-Witness & $0.00 \mathrm{a}$ & $12.50 \mathrm{a}$ & $41.67 \mathrm{~b}$ & $0.00 \mathrm{a}$ & $8.07 \mathrm{a}$ & $27.20 \mathrm{~b}$ \\
CV (\%) & 44.40 & 44.40 & 44.40 & 26.66 & 26.66 & 26.66 \\
\hline
\end{tabular}

Means followed by distinct letters in columns, differ by Scott Knott-5\% test. Data transformed into arc seno $\sqrt{x}$.

Among the products considered alternative, clove oil kept the incidence of brown rot low until six days after harvest. Probably due to the low residual power was not efficient in the evaluation of the nine days.

The efficiency of $\mathrm{K}$ phosphite has been demonstrated for other pathogens such as: apple-blue mold [19], reduction of Phytophtheracactorum lesions in apple trees [16], reduction of percentage of rotten fruits by Penicillium spp. in apple Fugi [28].

The benzalkonium chloride in curative tests, in works carried out by [26], with inoculation without injuries, was not effective in the control of Rhizopus spp. However, in this work, benzalkonium chloride applied in the flowering and preharvest phases significantly reduced the incidence of soft rot.

Silica applied through silicate clay did not reduce the incidence and severity of soft rot caused by Rhizopus spp., differing from results found for other diseases such as brown spot and bruzone in rice [21]; papaya smallpox [23] and cercosporiosis in coffee trees [24].

\section{Conclusions}

Iprodione significantly reduces the incidence and severity of brown rot in peach fruits and has no effect on soft rot.

Clove oil controls the incidence and severity of Monilinia fructicola until the fifth day after harvest and Rhizopus spp. until the sixth day.

$\mathrm{K}$ phosphite, benzalkonium chloride and azoxystrobin do not reduce the incidence of Monilinia fructicola and are efficient in controlling the incidence and severity of Rhizopus spp. until the ninth day after harvest.

\section{Acknowledgements}

To FAPEMIG, for the funding of this research. 


\section{Conflicts of Interest}

The authors declare no conflicts of interest regarding the publication of this paper.

\section{References}

[1] Andrade, J.C. (2014) Contribuição da pesquisa para o desenvolvimento da fruticultura na região do campo das Vertentes de Minas Gerais. Tese (Doutorado em Fitotecnia), Universidade Federal de Lavras, Lavras, 130 p.

[2] Raseira, M.C.B., Belarmino, L.C. and Franzon, R.C. (2018) Pessegueiro no mundo e no Brasil, TODAFRUTA.

https://www.todafruta.com.br/artigo-exclusivo-pessegeiro-no-mundo-e-no-Brasil

[3] De Andrade, E.R. (1995) Doenças do pessegueiro e da ameixeira e seu controle no estado de Santa Catarina. EPAGRI, Florianópolis, $52 \mathrm{p}$.

[4] Fortes, J.F. (2003) Principais Doenças. In: Raseira, M. Do C.B. and Centellas-Quezada, A., Eds., Informação Tecnológica, Embrapa, Pelotas, 107-114.

[5] Martins, C.M. and Amorim, L. (2005) Doenças das rosáceas de caroço. Informe Agropecuário, Belo Horizonte, 44-48,

[6] Feliciano, A. and Sachs, S.D. (1984) A cultura do pessegueiro. Embrapa, EMBRAPA-CNPFT, Circular Técnica, Pelotas, 89-101.

[7] Bleicher, J. (1997) Doenças de rosáceas de caroço. In: Kimati, H., Amorim, L., Bergamin, F., Camargo, L.E.A. and Rezende, J.A.M., Eds., Manual de Fitopatologia: Doenças das plantas cultivadas, 3rd Edition, Ceres, São Paulo, 621-627.

[8] Moreira, L.M. (1999) Controle químico e biológico de Monilinia fructicolae monitoramento de infecções latentes em frutos. Dissertação (Mestrado em ciências agrárias), Universidade Federal do Paraná, 76 p.

[9] May-De Mio, L.L., Garrido, L. and Veno, B. (2004) Doenças de fruteiras de caroço. In: Monteiro, L.B., May-De Mio, L.L., Serrat, B.M., Motta, A.C. and Cuquel, F.L., Eds., Fruteiras de Caroço: Uma visão ecológica, UFPR, Curitiba, 169-221.

[10] Girardi, C.L. (2001) Manejo Pós-Colheita e rastreabilidade da fruta na produção integrada. InformeAgropecuário, Belo Horizonte, 75-78.

[11] Hitokoto, H., Morozumi, S., Wauke, T., Sakai, S. and Kurata, H. (1980) Inhibitory Effects of Spices on Growth and Toxin Production of Toxigenic Fungi. Applied and Environmental Microbiology, 39, 818-822.

[12] Azzouz, M.A. and Bullerman, L.B. (1982) Comparative Antimycotic Effects of Selected Herbs, Spices, Planta Components and Commercial Anti-Fungal Agents. Journal of Food Protection, 45, 1298-1301, https://doi.org/10.4315/0362-028X-45.14.1298

[13] Shelef, L.A. (1983) Antimicrobial Effects of Spices. Journal of Food Safety, 6, 29-44. https://doi.org/10.1111/j.1745-4565.1984.tb00477.x

[14] Araújo, R. de C.Z. (2005) Embalagens ativas com ervas aromáticas e condimentares na conservação de pães artesanais. Dissertação (Mestrado em Ciência dos Alimentos), Universidade Federal de Lavras, Lavras, 88 p.

[15] Pereira, M.C. (2001) Efeito da adição de condimentos no controle de microrganismos, na conservação de produtos de panificação e na inibição de metabólitos produzidos por fungos associados ao café. Dissertação (Mestrado em Ciências dos Alimentos), Universidade Federal de Lavras, Lavras, 104 p.

[16] Bonetti, J.T. and Katsurayama, Y. (2002) Viabilidade do uso de fosfitos no manejo 
das doenças de macieira. In: Enfrute, V., Ed., Encontro Nacional Sobre Fruteiras de Clima Temperado, Epagri, Fraiburgo, 125-139.

[17] Reuveni, M., Sheglov, D. and Cohen, Y. (2003) Control of Moldy-Core Decay in Apple Fruits by â-aminobutyric Acids and Potassium Phosphates. Plantdisease, 87, 933-936.

[18] Moreira, L.M., May-De Mio, L., Valdebenito-Sanhueza, R.M., Lima, M.L.R.Z.C. and Passamai, J.C. (2002) Controle em pós-colheita de Moniliniafructicola em pêssego. Fitopatologia Brasileira, 27, 8.

[19] Blum, L.B., Amarante, C.V.T. do, Dezanete, A., Lima, E.B. de, Neto, P.H., Ávila, R.D. and Siega, V. (2007) Fosfitos aplicados em pós-colheita reduzem o mofo-azul em maçãs "Fugi" e "Gala". Revista Brasileira de Fruticultura, 29, 256-268.

[20] Savante, N.K., Korndorfer, G.H., Datnoff, L.E. and Snider, G.H. (1999) Silicon Nutrition on Sugar Cane Production a Review. Journal of Plant Nutrition, 22, 1853-1903.

[21] Korndorfer, G.H., Pereira, H.S. and Camargo, M.S. de (2002) Silicatos de cálcio e magnésio na agricultura. UFU/ICIAG, Uberlândia, 23 p.

[22] Datnoff, L.E., Snyder, G.H., Raid, R.N. and Jones, D.B. (1991) Effect of Calcium Silicate on Blast and Brawn Spot Intensities and Yields of Rice. Plant Disease, 75, 729-732.

[23] Pratissoli, D., Almeida, G.D. de, Junior, W.C.J., Vicentini, V.B., Holtz, A.M. and Cocheto, J.G. (2007) Fertilizante organomineral e argila silicatada como indutores de resistência à varíola do mamoeiro. Idesia, 25, 63-67. https://doi.org/10.4067/S0718-34292007000200008

[24] Pozza, E.A. and Pozza, A.A.A. (2003) Manejo de doenças de plantas com macro e micronutrientes. Fitopatologia Brasileira, 28, 52-54.

[25] Benato, E.A., Sigrist, J.M.M., Hanashro, M.M., Magalhães, M.J.M. and Binotti, C.S. (2002) Avaliações de fungicidas e produtos alternativos no controle de podridões pós-colheita em maracujá amarelo. Summa Phythopatologica, 28, 299-304.

[26] Abreu, F.M. de. (2006) Quantificação de danos e controle pós-colheita de podridão parda (Moniliniafructicola) e podridão mole (Rhizopus spp.) em pêssegos. Escola Superior Luiz de Queirós, Piracicaba, 95 p.

[27] Ferreira, D.F. (2000) Sisvar-Sistema de análises de variância para dados balanceados: Programa de análises estatísticas e planejamento de experimentos: Versão 4.3. UFLA-DEX, Lavras.

[28] Brackmann, A., Sestari, I., Giehl, R.F.H., Steffens, C.A., Faulin, G., Di, C. and Pinto, J.A.V. (2005) Controle de podridão pós-colheita de Penicillium spp., em maçã "Fuji" com fosfitos e fungicidas. Revista Brasileira Agrociência, 11, 251-254. 